\title{
Gold Mine Tailings: A Potential Source of Silica Sand for Glass Making
}

\author{
Uchenna Okereafor ${ }^{1, *(\mathbb{D})}$, Mamookho Makhatha ${ }^{1}$, Lukhanyo Mekuto ${ }^{2}$ (D) and \\ Vuyo Mavumengwana ${ }^{3}$ (D)
}

1 Department of Metallurgy, School of Mining, Metallurgy and Chemical Engineering, Faculty of Engineering and the Built Environment, University of Johannesburg, Johannesburg 2006, South Africa; emakhatha@uj.ac.za

2 Department of Chemical Engineering, School of Mining, Metallurgy and Chemical Engineering, Faculty of Engineering and the Built Environment, University of Johannesburg, Johannesburg 2006, South Africa; lukhanyom@uj.ac.za

3 South African Medical Research Council Centre for Tuberculosis Research, Division of Molecular Biology and Human Genetics, Department of Medicine and Health Sciences, Stellenbosch University, Stellenbosch 7600, South Africa; vuyom@sun.ac.za

* Correspondence: guokereafor@gmail.com; Tel.: +27-7475-16904

Received: 21 March 2020; Accepted: 25 April 2020; Published: 16 May 2020

check for updates

\begin{abstract}
Mining of minerals such as gold, copper, and platinum has been one of several activities sustaining the economy of South Africa. However, the mining sector has contributed significantly to environmental contamination through the improper disposal of mine tailings which covers vast areas of land. Therefore, this study utilised a vitrification process to manufacture glass from gold mine tailings. X-ray fluorescence was used to determine the chemical composition of the tailings while X-ray diffraction was adopted for the mineralogy. The tailings were of granitic composition enriched in potentially toxic elements such as copper, cadmium, zinc, lead, arsenic, and chromium. A representative sample of gold mine wastes of sandy grain size was used in making the glass. Based on composition, the glass was formulated by adding an average 10.0 mass $\%$ of $\mathrm{CaCO}_{3}$ and 5.0 mass $\%$ of $\mathrm{Na}_{2} \mathrm{CO}_{3}$ to 35.0 mass $\%$ of $\mathrm{SiO}_{2}$, which resulted in the production of a green-coloured glass.
\end{abstract}

Keywords: silica sand; beneficiation; characterization; gold mine tailings; glass; grain size

\section{Introduction}

Serious environmental risk are associated with mining wastes in a form of liquid and solid waste, which contain potentially toxic elements such as cadmium $(\mathrm{Cd})$, copper $(\mathrm{Cu})$, zinc $(\mathrm{Zn})$, lead $(\mathrm{Pb})$, chromium (Cr), arsenic (As), and vanadium (V) [1-3]. Among these environmental concerns are the solubilization of sulphides from pyritic mine tailings, which often results in acid mine drainages $[4,5]$.

The Gauteng province of South Africa is characterized by numerous mine tailing dumps which are a result of previously active mining activities. Several decades of mining activities in the Gauteng Province of South Africa has had and continues to have a negative impact on ecosystems through the pollution of soils and water with high levels of potentially toxic metals such as $\mathrm{As}, \mathrm{Pb}$, and $\mathrm{Al}$, as is the case with the old gold mine tailings in Blesbokspruit, Ekurhuleni South Africa [6-9]. Previous studies have reported cases of health-related complications among dwellers who reside nearer to these mine tailing sites as a result of the contamination of agricultural soils, water sources, and atmospheric air by these mine tailings and effluents [10-16].

Most gold mine tailings are composed mainly of industrial sand (i.e., silica) and silica sand is best described as a granular material that is composed of majorly quartz and trace amounts of coal, 
clay and other minerals [17]. In some instances, it is referred to as either quartz or industrial sand and is widely applied in many engineering applications. When silica sand is present in metallic materials, it could serve as a source of crevice corrosion on such metals. Silica sand is mechanically and chemically purified quartz sand, from which various products are made using processes such as hydro classification and thermal treatments [17]. The industrial application of silica sand is largely dependent on parameters such as the grain size, refractories, texture, and shape of the sample to be used [18]. Over the years, silica sand has remained a vital component in various engineering projects and applications including building product and abrasive, glass making and hydraulic fracturing of oil wells $[17,18]$. The essential Silicon Dioxide $\left(\mathrm{SiO}_{2}\right)$ required for glass formulation is provided by silica sand, which makes silica the basic component in all forms of glass. Although the production of glass requires a variety of different materials, silica represents over $75 \%$ of the final product [19]. Silica is hard, chemically inert and has a high melting point, which could be linked to the strength of the bonds between the atoms. These are prized qualities in applications like foundries and filtration systems. Quartz is the most common silica crystal; it may be transparent to translucent and has a vitreous luster, hence it is used in glassmaking and ceramics.

In 2003, South Africa based on silica as a mineral was reported to have 20 producers, 3 dormant mines, 2 decommissioned mines and 5 fume silica producers with most of the mining operations being in an opencast form [20]. The extracted silica sands are mostly from pegmatites, quartz massifs, veins or quartzites which are in the Western Cape, Mpumalanga and Gauteng regions [21]. The United States of America recorded an increase in silica sand production between 1996 and 1997 from 2.5 to 28.5 metric tons of which $37 \%$ was used in the manufacture of glass, $23 \%$ as foundry sand, $6 \%$ for hydraulic fracturing, and $5 \%$ as abrasives [22]. Continued usage of different forms of glass by individuals and organizations has necessitated an increasing global demand for the number of glass plants and industries [23-26].

As a waste disposal mechanism, the process of vitrification which involves the immobilization and encapsulation of radioactive and other types of hazardous materials at high temperatures (between $1100-1600{ }^{\circ} \mathrm{C}$ ) result in such materials melting into a liquid which, on cooling, transforms to an amorphous, glass-like solid [27]. This process could be employed if the obtained glass is recycled in high-value applications [28]. A herald of materials such as industrial wastes [29], fly ashes [30], sewage sludge [31] and pyrolized shales [32] are involved in some of these applications. The usage of the aforementioned materials is advantageous in that they have undergone diverse industrial processes that leave them with good homogeneity and finer particle size.

The production of glass using gold mine tailings as a major raw material could help decrease the volume of waste exposed to atmospheric processes thus averting ecological pollution while at the same time, contributing to economic earnings. Reports from previous studies on the physicochemical composition of mine tailings generated during the extraction of gold show close features with those frequently used raw materials in glassmaking processes $[33,34]$. The various environmental issues resulting from gold mine tailings had called for several scientific investigations to resolve the environmental burden that emanates from mine tailings. Some tailings dams have been partially or completely reclaimed leaving contaminated footprints. Some studies evaluated the potential to reuse mine tailings to produce bricks or ceramics $[35,36]$. In a recent study on gold tailings dam, it was found that the topsoil was highly acidified and only a minor portion of contaminants was bioavailable with the potential harm of phytotoxic contaminants such as $\mathrm{Co}, \mathrm{Ni}$, and $\mathrm{Zn}$ complicating rehabilitation measures as they limit the soil function [37]. In addition, soil samples from this study area in a recent investigation revealed trace element concentrations, which often exceeded background concentrations in soils [38]. Therefore, in a bid to extract value from gold mine tailings, this study was aimed at the quantification and qualification of gold mine tailings as a potential cheap silica source for the manufacture of glass. 


\section{Materials and Methods}

\subsection{Site Description and Sample Collection}

The study area (Figure 1) was situated in the eastern region of the East Rand Basin within the Blesbokspruit catchment $\left(26^{\circ} 10^{\prime} 12^{\prime \prime} S, 28^{\circ} 27^{\prime} 52^{\prime \prime} \mathrm{E}\right)$ in the Gauteng province of South Africa.

The materials used in this study included gold mine tailings (MT) that were logically collected from four different spots at an interval of $100 \mathrm{~m}$ for a fair representation of the area. Each sample was separately and carefully collected using a disinfected auger to drill vertically downwards to a depth of $20 \mathrm{~cm}$. This process was repeated at the different spots before transferring approximately $10 \mathrm{~kg}$ of each tailings material in labelled polyethylene bags designated MT1-MT4 for the purposes of identification. The tagged tailings samples were transported to the laboratory for preparation and further analysis.

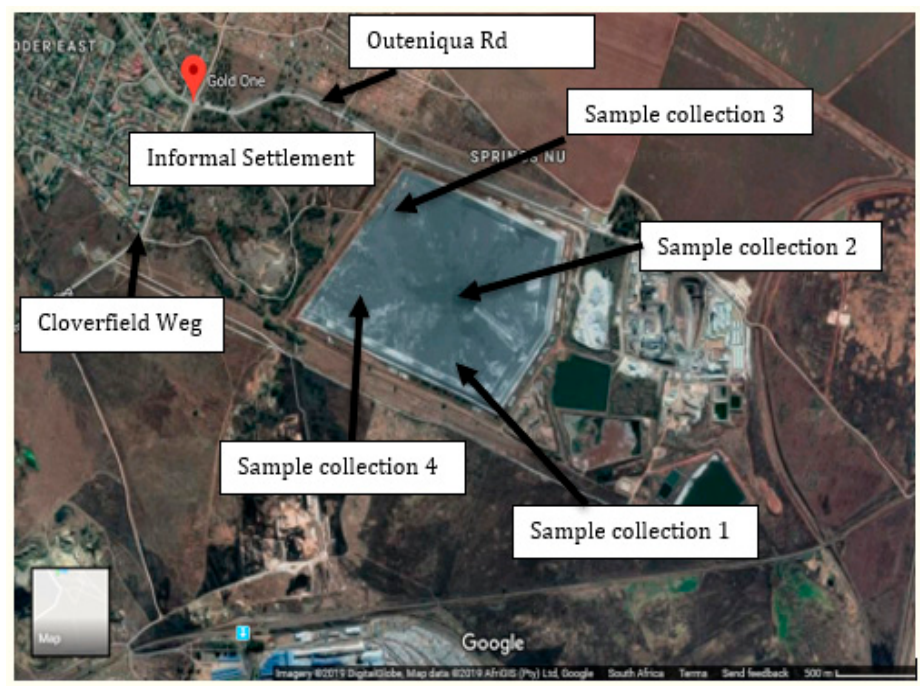

Figure 1. Location of the sampling site, $1 \mathrm{~cm}=500 \mathrm{~m}$.

\subsection{Sieve Analysis (Granulometric Distribution)}

Analysis of the grain-size of the silica sand from MT samples was determined using an electric sieving machine model (Filtra Vibracion SL-FTL 0200) operated under conditions of $230 \mathrm{~V}(50 / 60 \mathrm{~Hz})$ $2 \mathrm{~A}-400 \mathrm{~W}$ with a standard set of sieves. This was done to provide information on the percentage ideal fraction of the sample. $250 \mathrm{~g}$ of MT were weighed from each sample bag and thoroughly mixed in a pan for homogeneity to make a combined weight of $1000 \mathrm{~g}$. The set of sieves utilised was in the range of (10-150 Mesh), which is equivalent to 2000-105 microns. $1000 \mathrm{~g}$ of as received gold tailings material was properly dried in an oven at $100{ }^{\circ} \mathrm{C}$ for $30 \mathrm{~min}$ to ensure easy separation. Arrangement of the set of sieves was in ascending order of Mesh number with the pan at the bottom for the collection of the finest particles. The dried sample was poured onto the sieve at the top (10 Mesh), covered with a lid, and carefully fixed onto the electric sieve shaker, and subsequently agitated for 15 min. Each sieve beginning from the top was removed and the retained grain size was poured on a clean white paper. A brush was used to ensure all sand particles retained in each sieve were removed onto the paper. The weight of each collected grain size was determined using a Top pan balance model (Sartorius). The percentage retention of grain size was subsequently calculated $[39,40]$.

\subsection{Determination of Moisture Content and $\mathrm{pH}$}

Using a clean crucible, $24.95 \mathrm{~g}$ of a composite MT was poured and weighed $\left(\mathrm{W}_{1}\right)$ using an analytical balance. With the aid of an oven operated at $105^{\circ} \mathrm{C}$, the crucible containing the sample was heated for $1 \mathrm{~h}$ after which the new weight $\left(\mathrm{W}_{2}\right)$ was checked. The difference between both weights was determined and expressed as a percentage. 


$$
\text { Moisture content }=\frac{\mathrm{W} 1-\mathrm{W} 2}{\mathrm{~W} 1} \times 100
$$

The aim of measuring and controlling the moisture content of the samples is to ensure minimal casting defects that are associated with too much or too little organic materials within silica materials.

The $\mathrm{pH}$ of the samples was electronically determined using a Crison multimeter (model MM 41) of \pm 0.1 percent sensitivity that was calibrated using a buffer solution [41]. A representative sample of the tailings sediments was air-dried at room temperature for $6 \mathrm{~h}$. Afterward, using a chemical balance, $25 \mathrm{~g}$ of the dried sediments were weighed and poured into a clean beaker. This was done in triplicate. Subsequently, $40 \mathrm{~mL}$ of distilled water was added to each beaker using a volumetric cylinder. The solution was stirred with a glass rod and allowed to sit for $30 \mathrm{~min}$. While waiting, the pH meter was calibrated according to the manufacturer's instructions using two buffer solutions ( $\mathrm{pH} 4.0$ and $\mathrm{pH}$ 7.0). Before taking the $\mathrm{pH}$ readings of the sample, the mixtures were stirred again immediately. Precaution was taken not to place the electrode(s) directly in the sediment layer at the bottom of the beaker. Hence, the electrode(s) were positioned in the solution just above the sediment layer. After the initial reading (use), the electrode(s) were properly triple rinsed with distilled water before testing mixtures in beakers 2 and 3, respectively. The $\mathrm{pH}$ readings for the three mixtures were recorded to the nearest $0.1 \mathrm{pH}$ unit and the average reported.

\subsection{Determination of Clay Content}

$2.465 \mathrm{~kg}$ of composite MT were introduced into a clean head pan containing water and the mixture thoroughly rubbed using bear hands. Decantation of the brown water from the mixture was done and repeated several times until a clear water colouration was observed in the mixture. The water was then decanted leaving behind wet sand, which was air blown in a pressurized vacuum. The cake-like structure obtained was oven-dried at a temperature of $100{ }^{\circ} \mathrm{C}$ for $3 \mathrm{~h}$ [22]. The dried sample was reweighed and expressed as a percentage.

$$
\text { Percentage clay content }=\frac{\mathrm{m} 1-\mathrm{m} 2}{\mathrm{~m} 1} \times 100
$$

\subsection{Grain Morphology Test}

The shape of silica sand is an important factor in the manufacture of glass products. Using an electronic microscope model (Olympus BX41), the shape of a composite MT was revealed to ascertain their suitability for glass production.

\subsection{Specific Gravity Test}

With the aid of a specific gravity tester (model DH-300L), the specific gravity of a composite MT was directly obtained by introducing a very small sample into the equipment, which automatically conducted the test and displayed the values digitally on a visual display unit.

\subsection{Determination of Metal Oxides Concentration}

X-ray fluorescence (XRF) using a Sequential X-ray Spectrophotometer (XRF; Rigaku ZSX PrismusII) was used to determine the chemical compositions of each MT. The spectrometer was calibrated by a set of more than 60 international standards. $10 \mathrm{~g}$ of each of the four collected pulverised MT samples was mixed with a selected binder (PVC dissolved in toluene) before being pelletized using a mould at very high pressure. The pellets were oven-dried at $50^{\circ} \mathrm{C}$ for $1 \mathrm{~h}$ and subsequently placed in the sample compartment (Analyzer) of the spectrophotometer equipped with an end window $4 \mathrm{KW}$ Rh-anode X-ray tube-powered at a voltage and current of $40 \mathrm{KV}$ and $60 \mathrm{~mA}$ for heavy elements while the light elements were at $30 \mathrm{KV}$ and $100 \mathrm{~mA}$, respectively. 


\subsection{Determination of Mineralogy}

Using approximately $5 \mathrm{~g}$ of the oven-dried pulverized combination of the four collected representative MT samples, the XRD patterns were determined using a powder X-ray Diffractometer Model Rigaku Ultima IV with $\mathrm{CuK} \alpha$ radiation $\left(40 \mathrm{kV}\right.$ and $40 \mathrm{~mA}$ ) having a scanning range of $4-100^{\circ}$ with a $0.017^{\circ} 2 \theta$ step scan and a $50 \mathrm{~s}$ measuring time. The XRD aided the determination of the mineralogical composition of the material components and qualitative and quantitative phase analysis of multiphase mixtures. Individual reflection, as displayed by the $\mathrm{X}$-ray diffraction, corresponded to a mineral. With peaks distinctly separated from each other, their heights were used to determine the orientation of identified minerals in the mixture. Mineral analysis of the gold tailings samples by X-ray diffraction was based on the identification of various peaks and by comparison of their relative heights. Respective phase levels were identified as semi-quantitative estimates based on their relative peak heights using a PAN analytical X'Pert High Score software. A wavelength of 1.5406 was employed in the calculation of the diffraction angles.

\subsection{Removal of Metals through Leaching}

For the best outcomes, two acids were utilised, nitric $\left(\mathrm{HNO}_{3}\right)$ and sulphuric $\left(\mathrm{H}_{2} \mathrm{SO}_{4}\right)[42,43]$. In the first instance, $40 \mathrm{~g}$ of composite MT was weighed and poured into a $250 \mathrm{~mL}$ flask which was followed by the introduction of $100 \mathrm{~mL}$ of $1 \mathrm{M}$ nitric acid. The mixture was agitated at $850 \mathrm{rpm}$ using a magnetic stirrer on a hot plate at a temperature of $80{ }^{\circ} \mathrm{C}$ for $60 \mathrm{~min}$. Evaporation was prevented during the process by placing a watch glass over the flask. The samples were filtered using a Whatman filter paper and the residue thoroughly washed using a solution of $10 \%(2.5 \mathrm{M})$ Sodium hydroxide $(\mathrm{NaOH})$. The leaching process described above was done in duplicate. This was to further remove potential residual impurities from the silica sand surface. A subsequent filtration of the mixture was done followed by drying of the residue in an oven for $3 \mathrm{~h}[44,45]$. A similar process was repeated using $100 \mathrm{~mL}$ of $1 \mathrm{M}$ sulphuric acid and the percentage concentrations of metal oxides in each sample were evaluated using the procedure described in Section 2.7.

\subsection{Qualification Analysis as Glass Sand}

The qualification of extracted silica sand as potential glass sand was examined by the making of actual glass using silica from composite MT. Glass products were made from extracted silica sand from composite raw MT, water treated MT obtained from Section 2.4, and aid-treated samples from Section 2.9 using $\mathrm{CaCO}_{3}$ and $\mathrm{Na}_{2} \mathrm{CO}_{3}$ as fluxing agents. The mixtures were then heated in a muffle furnace at a temperature range of $1500-1600{ }^{\circ} \mathrm{C}$ for $2 \mathrm{~h}$. Four batches utilising each category of silica sand with a total mixture of $50 \mathrm{~g}$ in the ratio of 3:2:1 for silica, calcium carbonate, and sodium carbonate were used for the glass production. The mixtures were poured in four crucibles and carefully placed in the muffle furnace [46]. The role of the soda is to reduce the melting point of the silica sand, which in the long run will minimize energy consumption during manufacture. Unfortunately, industrial practices have discovered a drawback to the use of soda as it produces a kind of glass that would dissolve in water. However, the addition of limestone will mitigate the negative effect of soda [47]. Table 1 describes the batch compositions for glass production.

Table 1. Batch composition for glass production.

\begin{tabular}{cccccc}
\hline Sample Code & Description & Silica $(g)$ & $\mathbf{C a C O}_{3}(\mathbf{g})$ & $\mathbf{N a}_{2} \mathrm{CO}_{3}(\mathbf{g})$ & Temp. $\left({ }^{\circ} \mathbf{C}\right)$ \\
\hline $\mathrm{RT}$ & Raw tailings & 35.00 & 10.00 & 5.00 & 1520 \\
$\mathrm{WT}$ & Water treated tailings & 35.00 & 10.00 & 5.00 & 1520 \\
$\mathrm{THNO}_{3}$ & Nitric acid treated tailings & 35.00 & 10.00 & 5.00 & 1520 \\
$\mathrm{TH}_{2} \mathrm{SO}_{4}$ & Sulphuric acid treated tailings & 35.00 & 10.00 & 5.00 & 1520 \\
\hline
\end{tabular}




\section{Results and Discussion}

\subsection{Physical Analysis}

Table 2 presents a summary of some of the physical characteristic features of the MT. The percentage weight moisture content, which is a combined loss of volatile matter such as structural water $\left(\mathrm{H}_{2} \mathrm{O}\right)$ and carbon dioxide was observed to be $0.4 \%$. This moisture content value is an indication that the MT are suitable for use as silica for glass making due to the presence of moderate organic materials, hence the holding of little or no water within the silica system. This prevents the creation of gas defects in the final glass product [22].

A percentage of the clay content of $14.25 \%$ was obtained after washing and drying the raw MT (Figure 2). This is an indication that the grains are free of binders and will contain little or no water, which could cause bubbles and defects.

The water-soluble level of alkalinity or acidity of the silica sand from the MT is revealed by the $\mathrm{pH}$. A higher or lower $\mathrm{pH}$ indicates the presence of either acidic or basic oxides in each silica sand specimen, which in this case was found to be 4.28 . This value is close to neutral (7.00) and could be used for glass making [48].

The specific gravity value of 2.50 obtained in the analysis is an indication that the silica sand from MT is suitable for glassmaking since values above 2.65 are considered not suitable [49].

Table 2. Physical analysis of silica sand from mine tailings (MT).

\begin{tabular}{cc}
\hline Property & Silica Sand (MT) \\
\hline Moisture content $(\%)$ at $105{ }^{\circ} \mathrm{C}$ & 0.40 \\
Clay content $(\%)$ & 14.25 \\
$\mathrm{pH}$ & 4.28 \\
Grain shape & Subangular \\
Specific gravity & 2.50 \\
Appearance (colour) & Grey to light brown colouration. \\
\hline
\end{tabular}

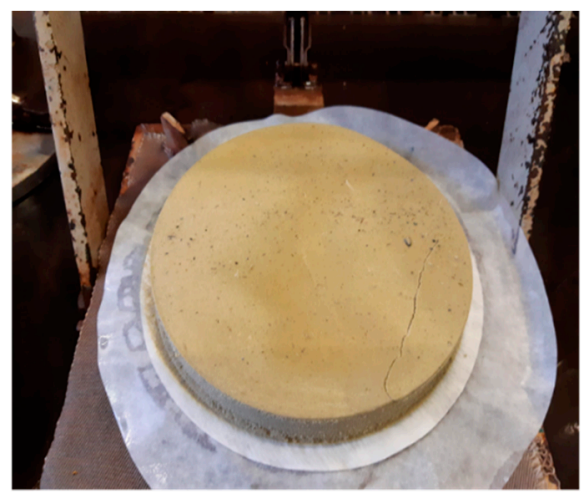

A. Washed Tailings

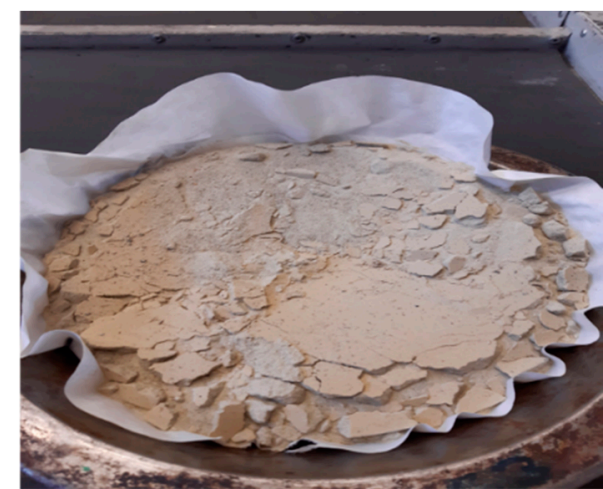

B. Dried Washed Tailings

Figure 2. Water treated silica sand from MT (Scale: $4.86 \mathrm{~cm} \times 13.02 \mathrm{~cm})$. (A): Washed tailings; (B): Dried washed tailings.

\subsection{Granulometric Analysis}

Table 3 illustrates the grain size distribution of the MT materials. The result revealed that the highest percentage retention fraction of the silica sand from the MT samples was within mesh number 53-100 (96\%). Large grain particles partially mix with other grains in a batch while air bubbles are created in the final glass product by fine grain. The size analysis conducted thus far indicated that the silica sand met the prescribed standard range of over $90 \%$ of particle size within the 15-100 mesh (BS sieve number) [50]. 
Table 3. Grain size distribution analysis of MT samples.

\begin{tabular}{cccc}
\hline Mesh No. & Serial Number & Weight of Particle $(\mathbf{g})$ & \% Composition \\
\hline 10 & 223257 & 11.72 & 1.17 \\
53 & 701184 & 951.61 & 95.16 \\
75 & 700749 & 9.34 & 0.93 \\
106 & 700774 & 7.65 & 0.77 \\
150 & 701185 & 3.99 & 0.40 \\
Pan & Nil & 8.90 & 0.89 \\
\hline
\end{tabular}

\subsection{Concentrations of Metal Oxides}

The percentage of chemical compositions of the MT is presented in Table 4 . The result revealed $\mathrm{SiO}_{2}$ as having the highest percentage composition in the sample with a value of $(88.72 \%)$ followed by $\mathrm{Al}_{2} \mathrm{O}_{3}(4.44 \%), \mathrm{K}_{2} \mathrm{O}(1.55 \%), \mathrm{Fe}_{2} \mathrm{O}_{3}(1.42 \%), \mathrm{TiO}_{2}(0.42 \%), \mathrm{MgO}(0.27 \%), \mathrm{CaO}(0.22 \%)$, and a smaller amount of other oxides such as $\mathrm{Na}_{2} \mathrm{O}, \mathrm{NiO}, \mathrm{ZnO}, \mathrm{BaO}, \mathrm{CuO}, \mathrm{MnO}$, and $\mathrm{PbO}$. The high percentage of $\mathrm{SiO}_{2}$ in the tailings material is an indication of the presence of silica sand, which is similar to the findings from previous studies [51-54]. Upon comparison of the observed percentage compositions of the gold tailings from this study with the international minimum standard of silica sand used for glass making (Table 5), it was evident that the concentration of $\mathrm{SiO}_{2}(88.72 \%)$ fell below the required threshold, which could be attributed to some mechanical and geological factors; $\mathrm{CaO}+\mathrm{MgO}$ fell within the minimum standard while those of $\mathrm{Al}_{2} \mathrm{O}_{3}, \mathrm{Fe}_{2} \mathrm{O}_{3}$, and $\mathrm{TiO}_{2}$ were above the stipulated standard. The concentration of $\mathrm{Fe}_{2} \mathrm{O}_{3}$ in any silica sand used for glass production determines the colour of such glass as a slight increase could result in a green, yellow or red colouration. In certain situations, the colouration is neutralized by the introduction of manganese resulting in a faint shade of purple colour [55]. Edem et al. (2014) while using silica sand deposits from a riverbed observed that a lower concentration of $\mathrm{Fe}_{2} \mathrm{O}_{3}$ resulted in the formation of tableware and lead crystal glass [22]. In contrast with de Melo et al. (2012), a homogeneous shiny dark brown-coloured glass composed of $40.0 \mathrm{wt} . \%$ of sandy tailing and $60 \mathrm{wt} . \%$ of steelwork slag was observed [56].

The high percentage of iron oxide is an indication that the silica sand is suitable for coloured and insulated glass as the iron content is above $1 \%$. The high alumina also supports the tensile strength and stability of the glass. The MT require beneficiation to reduce the level of iron, titanium, and aluminium as a way of increasing the number of areas for its utilization in the glass industry. The high concentration of $\mathrm{K}_{2} \mathrm{O}$ could be beneficial in increasing the refractive index of potential glass products [57].

Table 4. Result of chemical analysis of four representative MT samples.

\begin{tabular}{|c|c|c|c|c|c|c|c|c|c|c|c|c|c|}
\hline Sample & $\begin{array}{c}\mathrm{SiO}_{2} \\
\text { (wt.\%) }\end{array}$ & $\begin{array}{c}\mathrm{TiO}_{2} \\
\text { (wt.\%) }\end{array}$ & $\begin{array}{l}\mathrm{Al}_{2} \mathrm{O}_{3} \\
\text { (wt. \%) }\end{array}$ & $\begin{array}{l}\mathrm{Fe}_{2} \mathrm{O}_{3} \\
\text { (wt.\%) }\end{array}$ & $\begin{array}{c}\mathrm{MnO} \\
\text { (wt.\%) }\end{array}$ & $\begin{array}{c}\mathrm{MgO} \\
\text { (wt.\%) }\end{array}$ & $\begin{array}{c}\mathrm{CaO} \\
\text { (wt.\%) }\end{array}$ & $\begin{array}{l}\mathrm{Na}_{2} \mathrm{O} \\
\text { (wt.\%) }\end{array}$ & $\begin{array}{c}\mathrm{K}_{2} \mathrm{O} \\
\text { (wt.\%) }\end{array}$ & $\begin{array}{c}\mathrm{P}_{2} \mathrm{O}_{5} \\
\text { (wt.\%) }\end{array}$ & $\begin{array}{c}\mathrm{Pb} \\
(\mathrm{mg} / \mathrm{kg})\end{array}$ & $\underset{(\mathrm{mg} / \mathrm{kg})}{\mathrm{Zn}}$ & $\begin{array}{c}\mathrm{Cu} \\
(\mathrm{mg} / \mathrm{kg})\end{array}$ \\
\hline MT1 & 89.03 & 0.44 & 4.43 & 1.42 & 0.04 & 0.26 & 0.21 & 0.17 & 1.53 & 0.06 & 300 & 500 & 100 \\
\hline MT2 & 88.87 & 0.41 & 4.33 & 1.37 & 0.03 & 0.28 & 0.21 & 0.14 & 1.57 & 0.07 & 200 & 700 & 200 \\
\hline MT3 & 88.35 & 0.43 & 4.48 & 1.41 & 0.03 & 0.25 & 0.20 & 0.14 & 1.54 & 0.05 & 300 & 400 & 200 \\
\hline MT4 & 88.63 & 0.40 & 4.52 & 1.48 & 0.02 & 0.29 & 0.26 & 0.16 & 1.56 & 0.05 & 400 & 700 & 300 \\
\hline $\mathrm{MT}_{\mathrm{AVE}}$ & 88.72 & 0.42 & 4.44 & 1.42 & 0.03 & 0.27 & 0.22 & 0.15 & 1.55 & 0.05 & 300 & 500 & 200 \\
\hline
\end{tabular}

Table 5. General specification of the chemical composition of silica sand for glassmaking [50,58].

\begin{tabular}{ccccccc}
\hline Glass Type & Grade & $\mathbf{S i O}_{\mathbf{2}} \%$ & $\mathbf{F e}_{\mathbf{2}} \mathbf{O}_{\mathbf{3}} \%$ & $\mathbf{A l}_{\mathbf{2}} \mathbf{O}_{\mathbf{3}} \%$ & $\mathbf{C a O}+\mathbf{M g O} \%$ & $\mathbf{T i O}_{\mathbf{2}} \%$ \\
\hline Optical and ophthalmic glass & $\mathrm{A}$ & 99.800 & 0.013 & 0.200 & 0.100 & 0.000 \\
Tableware and lead crystal glass & $\mathrm{B}$ & 99.600 & 0.050 & 0.500 & 0.200 & 0.012 \\
Borosilicate glass & $\mathrm{C}$ & 98.500 & 0.150 & 0.500 & 0.500 & 0.100 \\
Colourless container ("flint”) & $\mathrm{D}$ & 95.000 & 0.200 & 4.000 & 0.500 & 0.100 \\
Clear flat glass & $\mathrm{E}$ & 95.000 & 0.300 & 0.500 & 0.500 & 0.100 \\
Coloured container glass & $\mathrm{F}$ & 95.000 & 1.000 & 4.000 & 0.500 & 0.100 \\
Insulating fibres & $\mathrm{G}$ & 94.500 & 1.000 & 4.000 & 0.500 & 0.100 \\
\hline
\end{tabular}




\subsection{Mineralogy}

Table 6 and Figure 3 each illustrate the principal minerals present in the silica sand from MT samples. The result reveals various principal minerals such as Quartz, Magnesioferrite, Marcasite, Magnetite, Kyanite, and Gupeite as present in the MT. Quartz in the form of silica $\left(\mathrm{SiO}_{2}\right)$ was the predominant mineral in the tailings, which based on its abundance, crystalline nature, high thermal, and chemical properties, could be utilised in many large-scale applications. With quartz as the dominating mineral, the silica sand from the MT could be considered for manufacture of container glass, flat plate glass, specialty glass, and fiberglass on account of its luster, colour, and diaphaneity.

Table 6. Principal minerals in silica sand from MT.

\begin{tabular}{cc}
\hline Mineral Present & Chemical Composition \\
\hline Quartz & $\mathrm{SiO}_{2}$ \\
Magnesioferrite & $\mathrm{MgO}_{6} \mathrm{O}_{6} \mathrm{FeO}_{94}$ \\
Marcasite & $\mathrm{FeS}_{2}$ \\
Magnetite & $\mathrm{Fe}_{3} \mathrm{O}_{4}$ \\
Kyanite & $\mathrm{Al}_{2}\left(\mathrm{SiO}_{4}\right) \mathrm{O}$ \\
Gupeite & $\mathrm{Fe}_{3} \mathrm{Si}$ \\
\hline
\end{tabular}

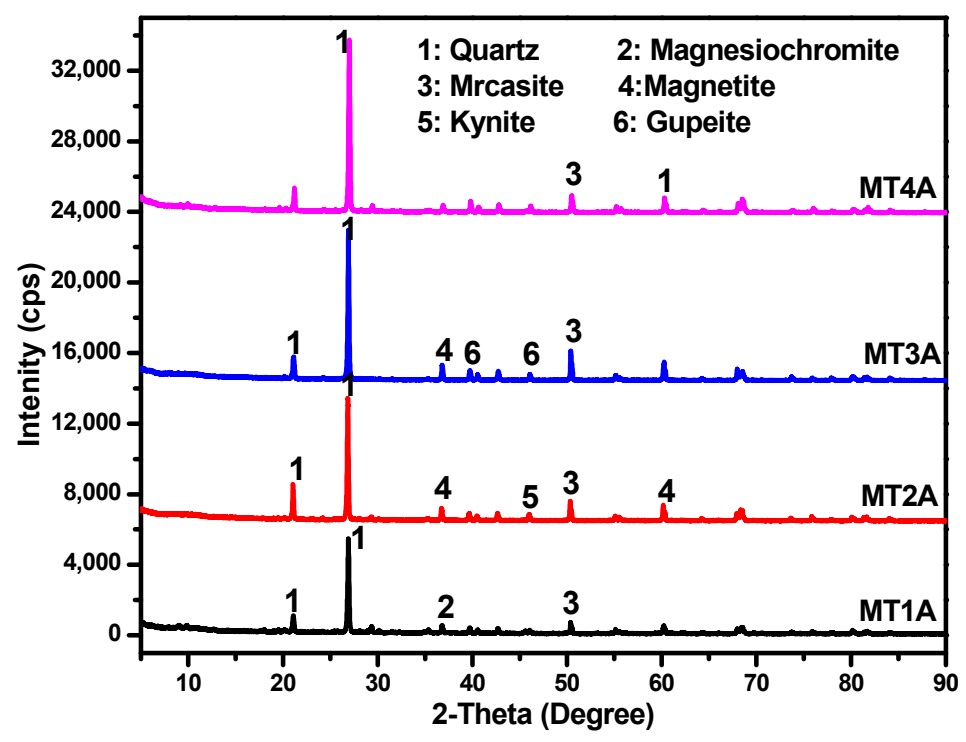

Figure 3. XRD patterns of silica sand from MT (Scale: $10.96 \mathrm{~cm} \times 15.48 \mathrm{~cm}$ ).

\subsection{Beneficiation of Silica Sand from MT}

After a physical separation technique using water and acid leaching of the materials as described in Section 2.4, Section 2.7, and Section 2.9 respectively, there was an appreciable increase in the silica content with a corresponding reduction in impurities such as iron oxide, alumina, titanium oxide, and potassium oxide respectively. A summary of the chemical composition of the treated silica sand is described in Table 7.

Table 7. Summary of the chemical composition of the extracted treated silica sand.

\begin{tabular}{|c|c|c|c|c|c|c|c|c|c|c|c|c|c|}
\hline Sample & $\begin{array}{c}\mathrm{SiO}_{2} \\
\text { (wt.\%) }\end{array}$ & $\begin{array}{c}\mathrm{TiO}_{2} \\
\text { (wt. } \% \text { ) }\end{array}$ & $\begin{array}{l}\mathrm{Al}_{2} \mathrm{O}_{3} \\
\text { (wt. \%) }\end{array}$ & $\begin{array}{l}\mathrm{Fe}_{2} \mathrm{O}_{3} \\
\text { (wt. } \% \text { ) }\end{array}$ & $\begin{array}{c}\mathrm{MnO} \\
\text { (wt. } \%)\end{array}$ & $\begin{array}{c}\mathrm{MgO} \\
\text { (wt.\%) }\end{array}$ & $\begin{array}{c}\mathrm{CaO} \\
\text { (wt.\%) }\end{array}$ & $\begin{array}{c}\mathrm{Na}_{2} \mathrm{O} \\
(w t . \%)\end{array}$ & $\begin{array}{c}\mathrm{K}_{2} \mathrm{O} \\
(w t . \%)\end{array}$ & $\begin{array}{c}\mathrm{P}_{2} \mathrm{O}_{5} \\
\text { (wt. \%) }\end{array}$ & $\begin{array}{c}\mathrm{Pb} \\
(\mathrm{mg} / \mathrm{kg})\end{array}$ & $\begin{array}{c}\mathrm{Zn} \\
(\mathrm{mg} / \mathrm{kg})\end{array}$ & $\begin{array}{c}\mathrm{Cu} \\
(\mathrm{mg} / \mathrm{kg})\end{array}$ \\
\hline A & 88.72 & 0.42 & 4.44 & 1.42 & 0.03 & 0.27 & 0.22 & 0.15 & 1.55 & 0.05 & 300 & 500 & 200 \\
\hline C & 89.53 & 0.33 & 2.31 & 1.31 & 0.01 & 0.18 & 0.18 & 0.10 & 1.17 & 0.02 & 200 & 300 & - \\
\hline D & 89.82 & 0.31 & 2.19 & 1.27 & 0.01 & 0.15 & 0.15 & 0.09 & 1.03 & 0.01 & 200 & 100 & - \\
\hline
\end{tabular}

NB: A = Raw Tailings, $\mathrm{B}=$ Water treated, $\mathrm{C}=\mathrm{HNO}_{3}$ treated tailings, $\mathrm{D}=\mathrm{H}_{2} \mathrm{SO}_{4}$ treated tailings. 


\subsection{Qualification Analysis}

The production of low melting glass was observed at a temperature of $1520{ }^{\circ} \mathrm{C}$ after $2 \mathrm{~h}$. The mixtures resulted in various glassy phase samples. The glassy material was not fully liquidised at this temperature and time, and hence could not be poured onto a mould. Upon cooling, the crucibles were carefully broken using a hammer to expose the final products as shown in Figure 4. Glassy phase formations from batch compositions (B) and (D) had noticeable green colouration, which could be linked to the iron content of the silica sand used. With batch compositions (A) and (C), there were whitish structures that could be due to the refining process. The materials from batch (D) demonstrated the highest quality of glass, which supports the industrial requirements as described in Table 5 and the study of Afonso et al. [59]. Batch (D) just like in a commercial glass plant, will have to be subjected to further processing by including waste glass (from recycling collections), and heated in a furnace. The green colour provided by iron oxide, could be neutralized by adding other metal oxides such as Zinc oxide to the molten glass to produce a white product [60].

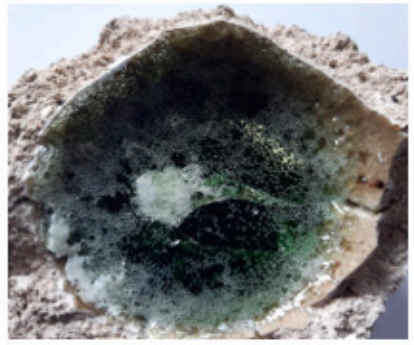

A. Raw Tailings

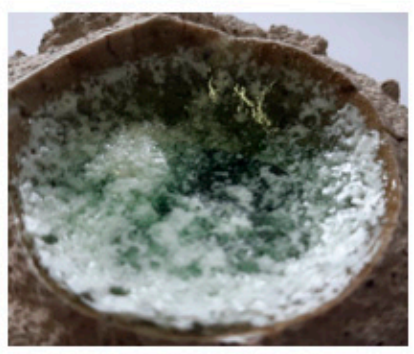

C. $\mathrm{HNO}_{3}$ Treated Tailings

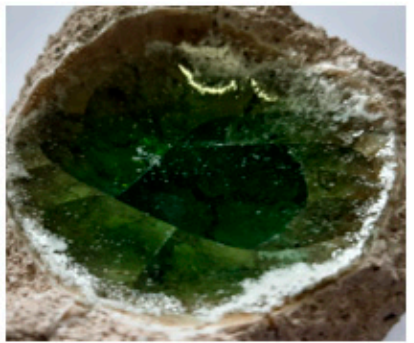

B. Water Treated Tailings

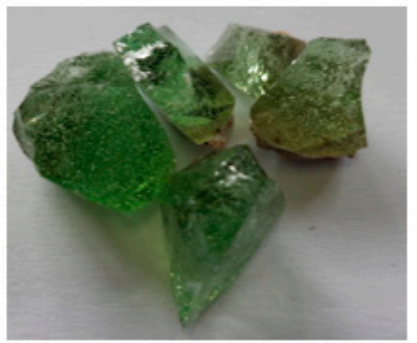

D. $\mathrm{H}_{2} \mathrm{SO}_{4}$ Treated Tailings

Figure 4. Glass samples produced from the various batch compositions. (A): Raw tailings; (B): Water treated tailings; (C): $\mathrm{HNO}_{3}$ treated; (D): $\mathrm{H}_{2} \mathrm{SO}_{4}$ treated.

\section{Conclusions}

For the first time, this study investigated MT as a source of silica in glassmaking to mitigate the negative environmental burden that these tailings possess. Based on the high percentage of silica in these mine tailings, which is a major constituent and other physical attributes such as grain size and morphology that met the requirements for glassmaking, the MT from this study could be a cheap and readily available source of silica sand for the glass manufacturing industry. Raw, water-treated, nitric acid-treated, and sulfuric acid-treated MT were tested to ascertain the quality of the glass material produced. Based on the observed qualification tests, the sulfuric acid-treated tailings produced a satisfactory green glass quality, while raw, water-treated and nitric acid-treated tailings showed white residues that reduced the quality of the glass. It is recommended that further beneficiation towards reducing the iron oxide on sulphuric acid-treated gold tailings be carried out to widen the application to other forms of glass and not limited to green-coloured and amber glass production.

Author Contributions: Conceptualization, M.M. and V.M.; methodology, U.O.; software, L.M.; validation, U.O., L.M. and V.M.; formal analysis, U.O.; investigation, U.O.; resources, M.M.; data curation, U.O.; writing-original draft preparation, U.O.; writing-review and editing, L.M. and V.M.; visualization, U.O.; supervision, M.M.; project administration, L.M. All authors have read and agreed to the published version of the manuscript. 
Funding: This research received no external funding.

Acknowledgments: We acknowledge the assistance of the Metallurgical engineering laboratories for providing the equipment used for this study.

Conflicts of Interest: The authors declare no conflicts of interest.

\section{References}

1. Tchounwou, P.B.; Yedjou, C.G.; Patlolla, A.K.; Sutton, D.J. Heavy metal toxicity and the environment. Exp. Suppl. 2012, 101, 133-164. [PubMed]

2. Krewski, D.; Yokel, R.A.; Nieboer, E.; Borchelt, D.; Cohen, J.; Harry, J.; Kacew, S.; Lindsay, J.; Mahfouz, A.M.; Rondeau, V. Human health risk assessment for aluminium, aluminium oxide, and aluminium hydroxide. J. Toxicol. Environ. Health. Part B Crit. Rev. 2007, 10, 1-269.

3. Ali, H.; Khan, E.; Ilahi, I. Environmental chemistry and ecotoxicology of hazardous heavy metals, environmental persistence, toxicity, and bioaccumulation. J. Chem. 2019, 2019, 6730305.

4. Oyewo, O.A.; Agboola, O.; Onyango, M.S.; Popoola, P.; Bobape, M.F. Current methods for the remediation of acid mine drainage including continuous removal of metals from wastewater and mine dump. In Bio-Geotechnologies for Mine Site Rehabilitation; Prasad, M.N.V., de Campos Favas, P.J., Maiti, S.K., Eds.; Elsevier: Amsterdam, The Netherlands, 2018; pp. 103-114. [CrossRef]

5. Favas, P.J.C.; Sarkar, S.K.; Rakshit, D.; Venkatachalam, P.; Prasad, M.N.V. Acid mine drainages from abandoned mines, hydrochemistry, environmental impact, resource recovery, and prevention of pollution. In Environmental Materials and Waste—Resource Recovery and Pollution Prevention; Prasad, M.N.V., Shih, K., Eds.; Elsevier: Amsterdam, The Netherlands, 2016; pp. 413-462. [CrossRef]

6. Singh, P.; Nel, A.; Durand, J.F. The use of bioassays to assess the toxicity of sediment in an acid mine drainage impacted river in Gauteng (South Africa). Water SA 2017, 43, 673-683.

7. Olobatoke, R.Y.; Mathuthu, M. Heavy metal concentration in soil in the tailing dam vicinity of an old gold mine in Johannesburg, South Africa. Can. J. Soil Sci. 2016, 96, 299-304.

8. CSIR. Characterising the Risk of Human Exposure and Health Impacts from Acid Mine Drainage in South Africa-"Final Project Report"; Mine Health and Safety Council: Pretoria, South Africa, 2013.

9. Fashola, M.O.; Ngole-Jeme, V.M.; Babalola, O.O. Heavy Metal Pollution from Gold Mines, Environmental Effects and Bacterial Strategies for Resistance. Int. J. Environ. Res. Public Health. 2016, 13, 1047. [CrossRef]

10. Okereafor, U.; Makhatha, M.; Mekuto, L.; Uche-Okereafor, N.; Sebola, T.; Mavumengwana, V. Toxic metal implications on agricultural soils, plants, animals, aquatic life and human health. Int. J. Environ. Res. Public Health 2020, 17, 2204.

11. Entwistle, J.A.; Hursthouse, A.S.; Marinho Reis, P.A.; Stewart, A.G. Metalliferous mine dust, human health impacts and the potential determinants of disease in mining communities. Curr. Pollut. Rep. 2019, 5, 67-83.

12. Ng, J.C.; Ciminelli, V.; Gasparon, M.; Caldeira, C. Health risk apportionment of arsenic from multiple exposure pathways in Paracatu, a gold mining town in Brazil. Sci. Total. Environ. 2019, 673, 36-43.

13. Ngole-Jeme, V.M.; Fantke, P. Ecological and human health risks associated with abandoned gold mine tailings contaminated soil. PLOS ONE 2017, 12, e0172517.

14. Momoh, A.; Mhlongo, S.E.; Abiodun, O.; Muzerengi, C.; Mudanalwo, M. Potential implications of mine dusts on human health: A case study of Mukula Mine, Limpopo Province, South Africa. Pak. J. Med Sci. 2013, 29, 1444-1446. [PubMed]

15. Nelson, G.; Murray, J.; Phillips, J.I. The risk of asbestos exposure in south african diamond mine workers. Ann. Occup. Hyg. 2011, 55, 569-577. [PubMed]

16. Plumlee, G.S.; Morman, S.A. Mine wastes and human health. Elements 2011, 7, 399-404.

17. Beňo, J.; Adamusová, K.; Merta, V.; Bajer, T. Influence of silica sand on surface casting quality. Arch. Foundry Eng. 2019, 19, 5-8.

18. Malu, S.P.; Edem, C.A.; Ita, B.I. Chemical characterization of silica sand deposit from River Katsina-ala, North Central Region of Nigeria. Glob. J. Pure Appl. Chem. Res. 2015, 3, $26-40$.

19. Hasanuzzaman, M.; Rafferty, A.; Sajjia, M.; Olabi, A. Properties of glass materials. In Reference Module in Materials Science and Materials Engineering; Lauter, V., Lauter, H., Glavic, A., Eds.; Elsevier: Amsterdam, The Netherlands, 2015. [CrossRef] 
20. Department of Minerals and Energy. Minerals Statistical Tables 1995-2016; Directorate, Mineral Economics: Pretoria, South Africa, 2017. ISBN 978-0-621-45963-0.

21. Department of Minerals and Energy. The Silica Industry in the Republic of South Africa; Directorate, Mineral Economics: Pretoria, South Africa, 2004. ISBN 1-919927-01-8.

22. Edem, C.A.; Malu, S.P.; Ita, B.I. Characterization and beneficiation of the glass making potentials of silica sand deposit from River Benue North Central Nigeria. J. Nat. Sci. Res. 2014, 4, 49-58.

23. Garside, M. Glass Industry—Statistics \& Facts; Statista: Hamburg, Germany, 2019.

24. Wesgro. Glass Sector Fact Sheet; Wesgro: Cape Town, South Africa, 2018.

25. Wintour, N. WP 310-The Glass Industry: Recent Trends and Changes in Working Conditions and Employment Relations; International Labour Office, Sectoral Policies Department: Geneva, Switzerland, 2015.

26. European Commission. Raising Productivity Growth, Key Messages from the European Competitiveness Report; Commission of The European Communities (SEC (2007) 1444): Brussels, Belgium, 2007.

27. Bingham, P.A.; Hand, R.J. Vitrified metal finishing wastes, I. Composition, density and chemical durability. J. Hazard. Mater. 2005, 119, 125-133.

28. Binhussain, M.A.; Marangoni, M.; Bernardo, E.; Colombo, P. Sintered and glazed glass-ceramics from natural and waste raw materials. Ceram. Int. 2014, 40, 3543-3551.

29. Pe'rez, J.A.; Terradas, R.; Seijas, M.M.; Manent, R.; Martı́nez, S. Inertization of industrial wastes in ceramics materials. Ind. Ceram. 1996, 16, 7-11.

30. Haugsten, K.E.; Gustavson, B. Environmental properties of vitrified fly ash from hazardous and municipal waste incineration. Waste Manag. 2000, 20, 167-176.

31. Garcia-Valles, M.; Avila, G.; Martinez, S.; Terradas, R.; Nogue's, J.M. Heavy metal-rich wastes sequester in mineral phases through a glass-ceramic process. Chemosphere 2007, 68, 1946-1953. [PubMed]

32. Rangel, B.F.; Viana, M.M.; Fonseca, M.V.A.; Dweck, J.; Tavares, L.M. Thermal characterization of a new green ceramic material by heating microscopy, thermogravimetry and differential thermal analysis. J. Therm. Anal. Calorim. 2015, 121, 115-125.

33. Vatalis, K.I.; Charalampides, G.; Platias, S.; Benetis, N.P. Market developments and industrial innovative applications of high purity quartz refines. Int. Conf. Appl. Econ. Procedia Econ. Financ. 2014, 14, 624-633.

34. Al-Harbi, O.A.; Khan, M.M. Utilization of local raw materials for the production of commercial glasses. Trends Appl. Sci. Res. 2009, 4, 176-187.

35. Kinnunen, P.; Ismailov, A.; Solismaa, S.; Sreenivasana, H.; Räisänen, M.; Levänen, E.; Illikainen, M. Recycling mine tailings in chemically bonded ceramics-A review. J. Clean. Prod. 2018, 174, 634-649.

36. Ye, C.; He, F.; Shu, H.; Qi, H.; Zhang, Q.; Song, P.; Xie, J. Preparation and properties of sintered glass-ceramics containing Au-Cu tailing waste. Mater. Des. 2015, 86, 782-787.

37. Rösner, T.; van Schalkwyk, A. The environmental impact of gold mine tailings footprints in the Johannesburg region, South Africa. Bull. Eng. Geol. Environ. 2000, 59, 137-148.

38. Okereafor, G.; Makhatha, M.; Mekuto, L.; Mavumengwana, V. Evaluation of trace elemental levels as pollution indicators in an abandoned gold mine dump in Ekurhuleni Area, South Africa. In Trace Elements in the Environment-New Approaches and Recent Advances; IntechOpen: London, UK, 2019. [CrossRef]

39. Sundararajan, M.; Ramaswamy, S.; Raghavan, P. Evaluation for the beneficiability of white silica sands from the overburden of Lignite mine situated in Rajpardi district of Gujarat, India. J. Miner. Mater. Charact. Eng. 2009, 8, 701-713.

40. ASTM D422-63. In Standard Test Method for Particle-Size Analysis of Soils; ASTM International: West Conshohocken, PA, USA, 2007.

41. Aris, A.Z.; Ismail, F.A.; Ng, H.Y.; Praveena, S.M. An experimental and modelling study of selected heavy metals removal from aqueous solution using Scylla serrataas biosorbent. Pertanika J. Sci. Technol. 2014, 22, 553-566.

42. Ko, T.; Chu, C. Evaluation of Acid Leaching on the Removal of Heavy Metals and Soil Fertility in Contaminated Soil. J. Chem. 2018, 2018, 5036581.

43. Haghi, H.; Noaparast, M.; Tonkaboni, S.Z.S.; Mirmohammadi, M. A new experimental approach to improve the quality of low grade silicathe combination of indirect ultrasound irradiation with reverse flotation and magnetic separation. Minerals 2016, 6, 121.

44. Veglio, F.; Passariello, B.; Abbruzzese, C. Iron removal process for high-purity silica sand production by oxalic acid leaching. Ind. Eng. Chem. Res. 1999, 38, 4443-4448. 
45. Tarasova, I.I.; Dudeney, A.W.L.; Pilurzu, S. Glass sand processing by oxalic acid leaching and photo catalytic effluent treatment. Miner. Eng. 2001, 14, 639-646.

46. Holand, W.; Deubener, J. Nucleation and Crystallization of glasses and glass-ceramics. In Frontiers in Materials; Mauro, J.C., Ed.; Corning Inc.: Corning, NY, USA, 2017.

47. Bourhis, E.L. Glass, Mechanics and Technology; Wiley-VCH: Weinheim, Germany, 2014.

48. Anaekwe, N.O.; Hassan, Y.M. Chemical evaluation of the glass making potentials of silica sand deposits along Cross river in Cross River State, South-East of Nigeria. Eur. J. Eng. Res. Sci. 2017, 2, 12-17.

49. Duvuna, G.A.; Ayuba, A. A study on silica sand quality in Yazaram and Mugulbu deposits for glass making. Niger. J. Technol. 2015, 34, 109-112.

50. Pisutti, D.; Prukswan, C.; Pornsawat, W.; Narin, S. Investigation of local quartz sand for application in glass industry. Adv. Geosci. 2008, 13, 23-29.

51. BS 2975-1:2004. In Sampling and Analysis of Glass-Making Sands. Methods for Sampling and Physical Testing of Glass-Making Sands; BIS: London, UK, 1988.

52. Babasaheb, A.B. Geological Exploration of Friable Quartzite (Glass Sand) Deposit of Jiajuri District (Phase I and II); Assam Mineral Exploration Cooperation: Nagpur, Nagaon, India, 2010; pp. 1-8.

53. Tomiyama, S.; Igarashi, T.; Tabelin, C.B.; Tangviroon, P.; Ii, H. Acid mine drainage sources and hydrogeochemistry at the Yatani mine, Yamagata, Japan: A geochemical and isotopic study. J. Contam. Hydrol. 2019, 225, 103502.

54. Tabelin, C.B.; Igarashi, T. Mechanisms of arsenic and lead release from hydrothermally altered rock. J. Hazard. Mater. 2009, 169, 980-990.

55. Heck, M.; Hoffmann, P. Analysis of early medieval glass beads, The raw materials to produce green, orange and brown colours. Mikrochim. Acta. 2002, 139, 71-76.

56. De Melo, V.A.R.; Lameiras, F.S.; Tolentino, E. Conversion of sandy tailing from banded iron formation exploitation into glass-ceramic materials. Mater. Res. 2012, 15, 15-20.

57. Hubert, M. Commercial Glass Compositions, Properties and Technical Considerations_Raw Materials; IMI-NFG Course on Processing in Glass; CelSian Glass \& Solar B.V.: Eindhoven, The Netherlands, 2015.

58. David, M.I. A Study of Silica sand Quality and End Uses in Surrey and Kent. 2011. Available online: http://www.Ist-glass.Istthings.com/articles/glasscolouring.html (accessed on 12 July 2011).

59. Alfonso, P.; Castro, D.; Garcia-Valles, M.; Tarrago, M.; Tomasa, O; Martınez, S. Recycling of tailings from the Barruecopardo tungsten deposit for the production of glass. J. Therm. Anal. Calorim. 2016, 125, 681-687.

60. Lockhart, B. The color purple, dating solarized amethyst container glass. Hist. Archaeol. 2006, 40, 45-56. 